LANGUAGE PROCESSING AND LANGUAGE ACQUISITION 


\section{STUDIES IN THEORETICAL PSYCHOLINGUISTICS}

VOLUME 10

\section{Managing Editors}

Thomas Roeper, Dept. of Linguistics, University of Massachusetts at Amherst Kenneth Wexler, Dept. of Brain and Cognitive Science, M.I.T., Cambridge, Mass.

\section{Editorial Board}

Robert Berwick, Artifical Intelligence Laboratory, M.I.T., Cambridge, Mass.

Manfred Bierwisch, Zentralinstitut für Sprachwissenschaft, Akademie der Wissenschaften der D.D.R.

Merrill Garrett, University of Arizona, Tucson

Lila Gleitman, School of Education, University of Pennsylvania

Mary-Louise Kean, University of California at Irvine

Howard Lasnik, University of Connecticut at Storrs

John Marshall, Neuropsychology Unit, Radcliffe Infirmary, Oxford

Daniel Osherson, M.I.T., Cambridge, Mass.

Yukio Otsu, Tokyo Gakugei University, Tokyo

Edwin Williams, University of Massachusetts at Amherst 


\title{
LANGUAGE \\ PROCESSING AND \\ LANGUAGE \\ ACQUISITION
}

\author{
Edited by \\ LYN FRAZIER \\ Department of Linguistics, \\ University of Massachusetts, \\ Amherst, U.S.A. \\ and \\ JILL DE VILLIERS \\ Department of Psychology, Smith College, \\ Northampton, U.S.A.
}

SPRINGER SCIENCE+BUSINESS MEDIA, B.V. 


\section{Library of Congress Cataloging-in-Publication Data}

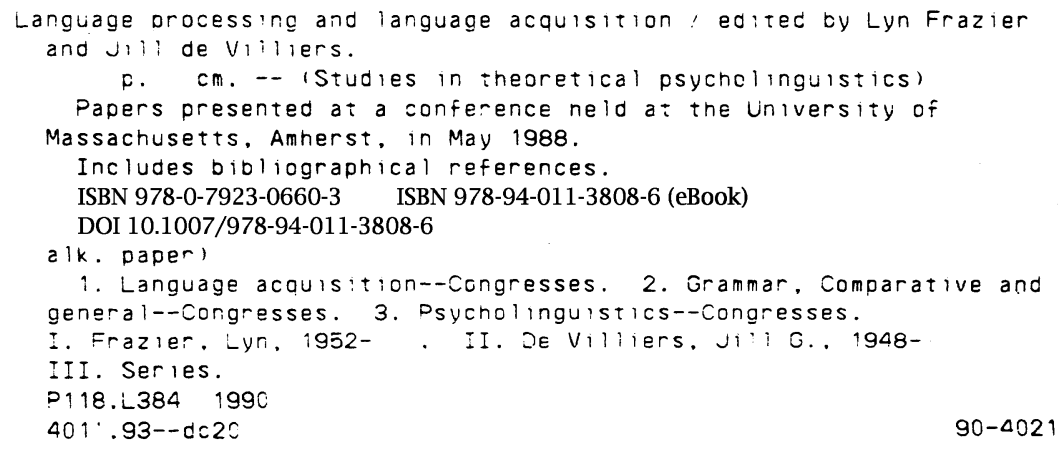

ISBN 978-0-7923-0660-3

\section{Printed on acid free paper}

All Rights Reserved

(C) 1990 Springer Science+Business Media Dordrecht

Originally published by Kluwer Academic Publishers in 1990

Softcover reprint of the hardcover 1st edition 1990

No part of the material protected by this copyright notice may be reproduced or utilized in any form or by any means, electronic or mechanical, including photocopying, recording or by any information storage and retrieval system, without written permission from the copyright owner. 
This book is dedicated to Charles Clifton

for his exceptional devotion to the field and those who play in it 


\section{TABLE OF CONTENTS}

ACKNOWLEDGMENTS

LYN FRAZIER and JILL DE VILLIERS / Introduction 1

DAVID LEBEAUX / The Grammatical Nature of the Acquisition Sequence: Adjoin-a and the Formation of Relative Clauses

ANNE VAINIKKA / The Status of Grammatical Default Systems: Comments on Lebeaux

KEN WEXLER / On Unparsable Input in Language Acquisition

VIRGINIA VALIAN / Logical and Psychological Constraints on the Acquisition of Syntax

THOMAS ROEPER and JÜRGEN WEISSENBORN / How to Make Parameters Work: Comments on Valian

REIKO MAZUKA and BARBARA LUST / On Parameter Setting and Parsing: Predictions for Cross-Linguistic Differences in Adult and Child Processing

NOBUKO HASEGAWA / Comments on Mazuka and Lust's paper

JANET DEAN FODOR / Parameters and Parameter-Setting in a Phrase Structure Grammar

JILL DE VILLIERS, THOMAS ROEPER and ANNE VAINIKKA / The Acquisition of Long-distance Rules 
viii

AMY WEINBERG / Child Grammars - Radically Different, or

More of the Same?: Comments on de Villiers, Roeper and Vainikka

DANA McDANIEL and HELEN SMITH CAIRNS / The Processing and Acquisition of Control Structures by Young Children

GREG N. CARLSON / Intuitions, Category and Structure: Comments on McDaniel and Cairns

STEPHEN CRAIN, CECILE McKEE and MARIA EMILIANI/ Visiting Relatives in Italy

JANE GRIMSHAW and SARA THOMAS ROSEN / Obeying the Binding Theory

HELEN GOODLUCK / Knowledge Integration in Processing and Acquisition: Comments on Grimshaw and Rosen 


\section{ACKNOWLEDGMENTS}

This volume reports papers presented at the University of Massachusetts Conference on 'Language Processing and Language Acquisition' held in Amherst on May 7-8, 1989. The conference was supported by N.I.H. Training Grant \# HD-07327. We wish to thank the authors not only for their papers and commentary, but also for reviewing each other's papers. We are also grateful to Emmon Bach, Tova Rappaport, Juli Carter, Greg LaMontagne and especially Tom Roeper for help with many stages of the conference and proceedings. Special thanks go to Maggie Browning for the excellent commentary she provided at the conference, and to Kathy Adamczyk for her extensive help and organizational wizardry. 